\title{
Comparison of contrast sensitivity between three aspheric acrylic monofocal intraocular lenses: a prospective randomised trial
}

Chin Chiet Ying Alice ${ }^{1,2}$, Banumathi Gurusamy ${ }^{3}$, Lim Keat Andrew ${ }^{1}$, Mae-Lynn Catherine Bastion ${ }^{2}$

${ }^{1}$ Department of Ophthalmology, Hospital Pulau Pinang, Georgetown, Pulau Pinang, Malaysia; ${ }^{2}$ Department of Ophthalmology, Hospital Canselor Tuanku Muhriz, Universiti Kebangsaan Malaysia Medical Centre (UKMMC), Cheras, Kuala Lumpur, Malaysia; ${ }^{3}$ Island Hospital Penang, Georgetown, Pulau Pinang, Malaysia

\section{Abstract}

Introduction: Evolution of cataract surgery and implantation of intraocular lenses (IOL) with new technological designs to optimise functional vision has been the aim of cataract surgery today. Aspherical lens design is a new lens technology to counteract spherical aberration exerted by a conventional IOL.

Purpose: To compare the contrast sensitivity after cataract surgery between aspheric IOLs with negative spherical aberration (Tecnis ZA9003 ${ }^{\mathrm{TM}}$ and AcryS of IQ ${ }^{\mathrm{TM}}$ ) and zero spherical aberration IOLs (Akreos Adapt Advance Optic [AO $]^{\mathrm{TM}}$ ).

Study design: Interventional, single-blinded, randomised controlled trial.

Methods: Ninety-six patients were recruited with 32 eyes in each study arm. All patients underwent standard phacoemulsification with implantation of an aspheric acrylic IOL randomised to one of the three lens models by a single experienced surgeon. Pre- and postoperative contrast sensitivity was analysed using the CSV1000E chart under photopic and mesopic conditions with and without glare testing.

Correspondence: Dr. Mae-Lynn Catherine Bastion, Professor of Ophthalmology (Vitreoretina) and Senior Consultant Ophthalmologist in Vitreoretinal Surgery, Department of Ophthalmology, Hospital Canselor Tuanku Muhriz, Jalan Yaacob Latif, 56000, Cheras, Kuala Lumpur, Malaysia.

E-mail:maelynnbdr@gmail.com 
Results: All three lenses showed statistically significant improvement in contrast sensitivity postoperatively at all spatial frequencies under photopic, mesopic, and scotopic conditions with glare. There was no statistically significant difference between the groups. Tecnis ZA9003 ${ }^{\mathrm{TM}}$ showed marked improvement in mesopic contrast sensitivity at 18 cycles/degree $(c p d)$ at 12 weeks $(p<0.05)$. The zero aberration Akreos Adapt $\mathrm{AO}^{\mathrm{TM}}$ showed better photopic contrast sensitivity compared to mesopic contrast sensitivity $(p>0.05)$.

Conclusion: AcrySof IQ ${ }^{\mathrm{TM}}$, Akreos Adapt $\mathrm{AO}^{\mathrm{TM}}$, and Tecnis ZA9003 ${ }^{\mathrm{TM}}$ performed equally well in contrast sensitivity at all spatial frequencies under photopic and mesopic conditions with and without glare testing. All lenses had statistically significant improvement in contrast sensitivity after cataract surgery. The negative aberration IOL Tecnis ZA9003 ${ }^{\mathrm{TM}}$ showed marked improvement in mesopic contrast sensitivity at $18 \mathrm{cpd}$ at 12 weeks. The zero aberration IOL, Akreos Adapt $\mathrm{AO}^{\mathrm{TM}}$ showed better photopic contrast sensitivity compared to mesopic contrast sensitivity.

Keywords: aspheric intraocular lenses, cataract, contrast sensitivity, CSV1000E chart, glare

\section{Perbandingan kepekaan kontras di antara tiga kanta intraokular monofocal akrilik aspherik: Kajian prospektif rawak}

\section{Abstrak}

Pengenalan: Evolusi pembedahan katarak dan implantasi kanta intraokular (IOL) dengan reka bentuk teknologi baru untuk mengoptimumkan fungsi penglihatan telah menjadi matlamat pembedahan katarak hari ini. Reka bentuk kanta aspherikal adalah teknologi kanta baru untuk mengatasi penyimpangan sfera yang diberikan oleh IOL konvensional.

Tujuan: Untuk membandingkan kepekaan kontras selepas pembedahan katarak antara IOL aspherik dengan penyimpangan sfera negatif (Tecnis ZA9003TM dan AcrySof IQTM) dan sifar sfera IOL (Akreos Adapt Advance Optic [AO] TM). Reka bentuk kajian: Kajian terkawal intervensi, single-blinded, terkawal.

Kaedah: Sembilan puluh enam pesakit direkrut dengan 32 mata di setiap kumpulan kajian. Semua pesakit menjalani fakoemulsifikasi rutin dengan implantasi IOL akrilik asfera dirawak daripada salah satu daripada tiga model kanta oleh satu pakar bedah berpengalaman. Kepekaan kontras pra dan pasca operasi dianalisis dengan menggunakan carta CSV1000E di bawah keadaan photopic dan mesopic dengan dan tanpa ujian silau. 
Hasil: Semua tiga kanta menunjukkan peningkatan ketara secara statistik dalam sensitiviti kontras selepas operasi di semua frekuensi spatial di bawah keadaan photopic, mesopic, dan scotopic dengan silau. Tiada perbezaan statistik secara signifikan antara kumpulan. Tecnis ZA9003TM menunjukkan peningkatan sensitiviti sensitiviti kontras mesopik pada 18 kitaran / darjah (cpd) pada 12 minggu ( $\mathrm{p}<0.05)$. Kesalahan sifar Akreos Adapt AOTM menunjukkan kepekaan kontras fotopik yang lebih baik berbanding kepekaan kontras mesopik ( $\mathrm{p}>0.05$ ). Kesimpulan: AcrySof IQTM, Akreos Adapt AOTM, dan Tecnis ZA9003TM dilakukan sama rata dengan kepekaan kontras di semua frekuensi spasial di bawah keadaan photopic dan mesopic dengan dan tanpa ujian silau. Semua kanta mempunyai peningkatan ketara secara statistik dalam kepekaan kontras selepas pembedahan katarak. Penyimpangan negatif IOL Tecnis ZA9003TM menunjukkan peningkatan yang ketara dalam kepekaan kontras mesopik pada 18 cpd pada 12 minggu. IOL penyimpangan sifar, Akreos Adapt AOTM menunjukkan kepekaan kontras fotopik yang lebih baik berbanding kepekaan kontras mesopik.

Kata kunci: carta CSV1000E, kanta intraokular aspherik, katarak, kepekaan kontras, silau

\section{Introduction}

Opacification of the crystalline lens or cataract is responsible for sixteen million cases of blindness worldwide, resulting in visual disability and decreased quality of life. ${ }^{1}$ Studies show an increasing prevalence with age, from $7 \%$ in the mid-forties to more than $90 \%$ in those 70 years and older. ${ }^{1}$ Zainal et al. reported that cataract accounted for nearly $40 \%$ of the total estimated cases of bilateral blindness, making cataract the major cause of blindness in Malaysia. ${ }^{2}$ The 10th Malaysian National Eye Database (MNED) Report in 2018 stated that the total number of cataract surgeries had increased from 18,426 in 2007 to 50,624 in 2016. ${ }^{3}$

The MNED also reported a change in type of cataract surgery from predominantly extracapsular cataract extraction (ECCE) at $30.1 \%$ in 2007 to phacoemulsification at $89.6 \%$ in $2016 .{ }^{3}$ The best corrected visual outcome of cataract surgery in the Ministry of Health Malaysia hospitals ( $\mathrm{MOH}$ ) likewise improved with $92.9 \%$ of operated eyes achieving best corrected vision of $6 / 12$ with phacoemulsification compared to $81.4 \%$ of ECCE patients at 12 weeks postoperative. ${ }^{3}$

For decades, the aim of ophthalmic surgeons worldwide has been to achieve a visual acuity of $6 / 6$. However, visual acuity is only one component of functional vision. Postoperatively, patients with $6 / 9$ vision or better may still complain of haziness, glare, and poor night vision despite good visual acuity. ${ }^{4}$ Conventional methods of evaluating the optical performance of intraocular lens (IOL) postoperatively using high-contrast letters on white background, such as the Snellen chart, 
describes only one part of the patient's functional vision. ${ }^{5,6}$ Measuring contrast sensitivity under different lighting conditions and various spatial frequencies provides a better picture of the patient's functional vision. ${ }^{5,7,8}$

Contrast sensitivity is a measure of the difference in brightness between two points of an image. It is the ratio between the minimum luminance subtracted from the maximum luminance and the average luminance, expressed in values ranging from 0 to 1 . It is also defined as the inverse of the measured contrast threshold.

Studies have shown a relationship between contrast sensitivity and visual performance. Loss of scotopic vision in older adults has been correlated with an increase in the risk of falling with hospitalization ${ }^{9}$ and difficulties in night driving. ${ }^{10}$ Postoperative contrast sensitivity can be affected by various factors such as optic design, ${ }^{4}$ decentration, and tilt of IOL. ${ }^{11}$

The conventional spherical IOL has positive spherical aberration. Therefore, its implantation does not counteract the positive spherical aberration of the cornea. This will result in poor postoperative image. ${ }^{12-14}$ Aspherical IOLs are designed to counteract the positive aberration of the cornea, ${ }^{5}$ thus simulating the conditions in a young patient with a functioning, clear crystalline lens. ${ }^{15}$ The negative aberration aspherical IOL is designed to leave no residual aberration. Aberration zero aspheric IOLs are designed to leave a small amount of positive aberration from the cornea.

Several studies $5,6,14,16-19$ comparing contrast sensitivity between spherical IOLs and aspherical IOLs have shown that aspherical IOLs provide better contrast sensitivity, especially at mesopic contrast and higher spatial frequencies. Other studies, ${ }^{20,21}$ however, reported no significant difference in visual function between spherical and aspherical IOLs. Therefore, for this study, an aspheric IOL with zero spherical aberration (Akreos Advance Optic ${ }^{\mathrm{TM}}[\mathrm{AO}]$, Bausch and Lomb, Quebec, Canada) and aspheric IOLs with negative spherical aberration (Tecnis ZA9003 ${ }^{\mathrm{TM}}$, Advanced Medical Optics, CA USA and AcrySof IQ ${ }^{\mathrm{TM}}$, Alcon Laboratories, TX, USA) were selected for study. These lenses are popular and still widely used in Malaysia.

All these lenses are monofocal and made of acrylic material. The material is cross-linked copolymer consisting of an acrylate/methacrylate copolymer producing a flexible property which enables it to unfold in a controlled manner. ${ }^{22}$ The AcrySof IQ ${ }^{\mathrm{TM}}$ and Tecnis ZA9003 ${ }^{\mathrm{TM}}$ are hydrophobic lenses. The Akreos Adapt $\mathrm{AO}^{\mathrm{TM}}$ is a hydrophilic lens.

The aim of this study is to compare the contrast sensitivity and visual outcomes of patients with an IOL with zero spherical aberration (Akreos Adapt $\mathrm{AO}^{\mathrm{TM}}$ ) and patients with an aspheric IOL with negative spherical aberration (Tecnis ZA9003 ${ }^{\mathrm{TM}}$ and AcrySof $\mathrm{IQ}^{\mathrm{TM}}$ ) after standard uneventful phacoemulsification in Malaysian patients. 


\section{Materials and methods}

This study was an interventional, single-blinded, randomised, controlled trial study. Patients attending the outpatient ophthalmology clinic at Hospital Pulau Pinang planned for cataract operation from June 2007 to March 2010 were recruited. Hospital Pulau Pinang, located in Penang, Malaysia, is a busy public general hospital managed by the Ministry of Health. Ethical approval for the study was obtained from the Secretariat National Institutes of Health (NIH), Ministry of Health Malaysia under project code MRG-2007-04. Written, informed consent was obtained from all patients.

The criteria for inclusion into the study was cataract with preoperative best corrected visual acuity (BCVA) of $6 / 60$ or better and postoperative vision of $6 / 15$ (logMAR 0.40) at 6 weeks postoperative in patients aged 55-75 years. Study patients provided written consent and were able to communicate and follow up with contrast sensitivity tests postoperatively.

Patients who had any ocular abnormalities or systemic diseases that could interfere with or affect contrast sensitivity such as diabetes mellitus, glaucoma, and any macular disease, such as age-related macular degeneration, were excluded from the study. Patients who had intraoperative complications such as posterior capsule rupture and anterior chamber lens or sulcus lens implantation, patients with postoperative complications such as postoperative endophthalmitis, secondary inflammatory glaucoma, postoperative cystoid macula oedema, significant posterior capsular opacification, and corneal decompensation were likewise excluded.

The visual acuity test, A-scan, refraction, and K-reading were performed by a trained optometrist. Routine preoperative investigations also included blood investigations for blood urea and serum electrolyte, full blood count and random blood sugar, electrocardiograms and a physical examination to exclude diabetics and ensure fitness for surgery. Preoperative ocular examinations included lid and anterior segment examination, intraocular pressure measurement, and lens and dilated fundal examinations. All patients had baseline contrast sensitivity testing prior to surgery. An algorithm showing the flow of the data collection is in Figure 1.

Visual acuity was tested using the logarithm of minimum angle of resolution (logMAR) chart. Contrast sensitivity was measured using the sine-wave grating CSV-1000E contrast sensitivity chart (VectorVision, Inc., OH, USA) (Fig. 2). This contrast sensitivity test uses sine-wave grating on a calibrated illuminated wall chart. It provides four rows of sine-wave gratings at spatial frequencies of 3, 6, 12, and 18 cycles/degree (cpd). Each cycle contains 17 round circles with sine-wave gratings. The test patches are arranged in upper and lower rows with eight levels of contrast.

The contrast levels decrease from left to right in logarithmic steps of 0.17 log units for steps 1 to 3 and $0.15 \log$ units for steps 3 to 8.23 Logarithmic contrast sensitivity was used for analysis. The measurements were performed with a $5.0 \mathrm{~mm}$ artificial 


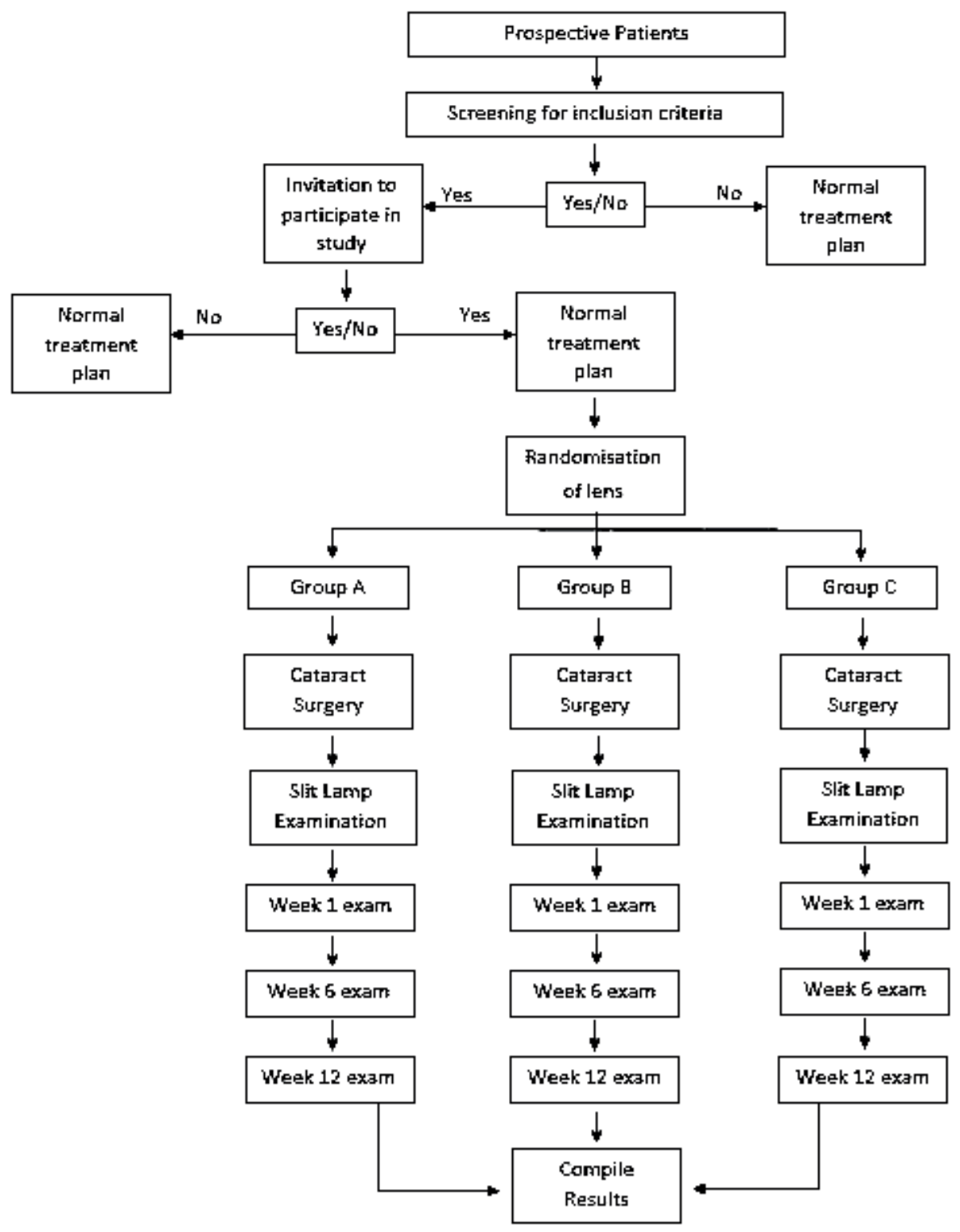

Fig. 1. Algorithm of data collection. 

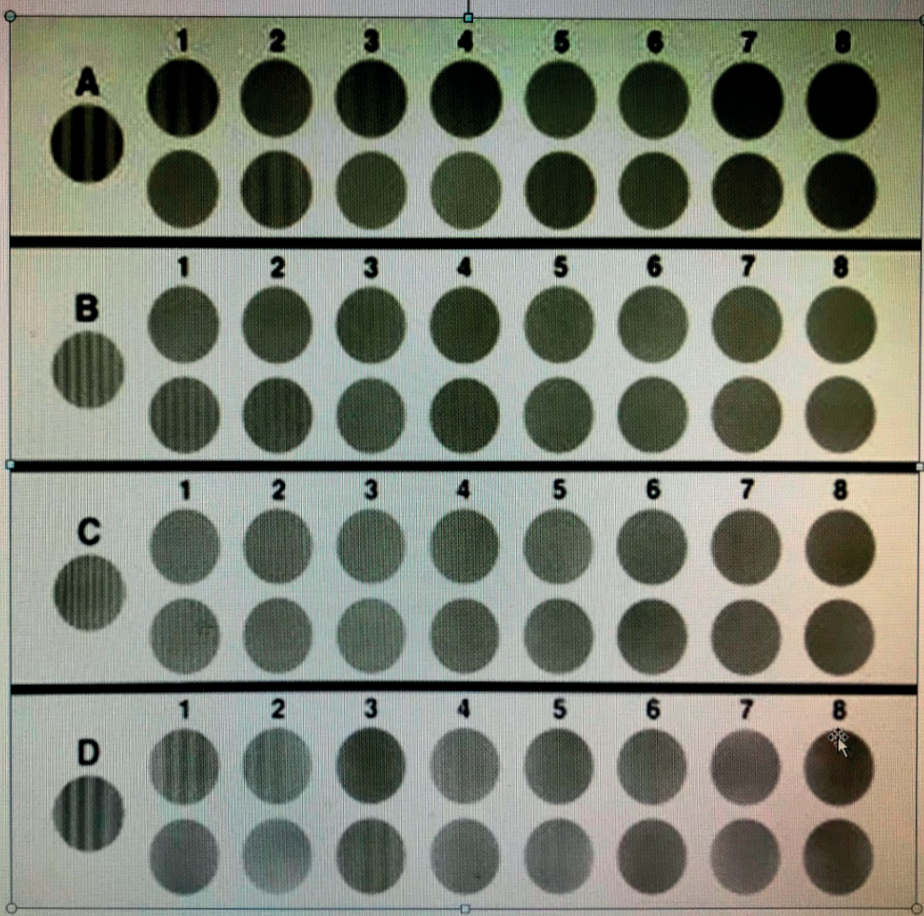

Fig. 2. CSV-1000e contrast sensitivity chart.

pupil in a trial frame. The pupil was dilated with two drops of tropicamide $0.5 \%$ and two drops of phenylephrine $2.5 \%$. Once the pupil was dilated, the contrast sensitivity testing began with a corrective lens and artificial pupil in place.

The patient was positioned at 2.5 metres from the chart and was asked to report which grating on the chart was the clearest. The test was conducted under photopic conditions and mesopic conditions, the latter with and without glare. Photopic testing was performed with standard lighting, which was provided by the internal fluorescent luminance console calibrated to 85 candelas per square metre $(\mathrm{cd} / \mathrm{m} 2)$. Mesopic testing without glare $(5 \mathrm{~cd} / \mathrm{m} 2)$ was performed by turning off the room light with the test conducted in a fully darkened room. Mesopic testing with glare was performed with a halogen light source of 200 lux positioned at the side of the console.

The patient reported whether the upper or lower circle had sine-wave gratings and the investigator recorded the last correct response as the contrast threshold. If the patient was unable to see the sample gratings, 0.30 log value was subtracted from the lowest score on the row. For example, Row $A$ is $(0.70-0.30)=0.40 \log$ unit (Table 1). 
Table 1. Contrast sensitivity values for CSV-1000E in log units

\begin{tabular}{|l|l|l|l|l|l|l|l|l|l|}
\hline \multirow{2}{*}{$\begin{array}{l}\text { Row } \\
\text { (cpd) }\end{array}$} & \multicolumn{2}{|l|}{ Plate } & \multicolumn{10}{|l|}{} \\
\cline { 2 - 10 } & Sample & $\mathbf{1}$ & $\mathbf{2}$ & $\mathbf{3}$ & $\mathbf{4}$ & $\mathbf{5}$ & $\mathbf{6}$ & $\mathbf{7}$ & $\mathbf{8}$ \\
\hline $\begin{array}{l}\text { A } \\
(3.0)\end{array}$ & 0.70 & 1 & 1.17 & 1.34 & 1.49 & 1.63 & 1.78 & 1.93 & 2.08 \\
\hline $\begin{array}{l}\text { B } \\
(6.0)\end{array}$ & 0.91 & 1.21 & 1.38 & 1.55 & 1.70 & 1.84 & 1.99 & 2.14 & 2.29 \\
\hline $\begin{array}{l}\text { C } \\
(12.0)\end{array}$ & 0.61 & 0.91 & 1.08 & 1.25 & 1.40 & 1.54 & 1.69 & 1.84 & 1.99 \\
\hline $\begin{array}{l}\text { D } \\
(18.0)\end{array}$ & 0.17 & 0.47 & 0.64 & 0.81 & 0.96 & 1.10 & 1.25 & 1.40 & 1.55 \\
\hline
\end{tabular}

The grating pattern contrast in the CSV-1000E test is expressed in Michelson contrast $=\left(\mathrm{L}_{\max }\right.$ $\left.-L_{\min }\right) /\left(L_{\max }+L_{\min }\right)$, where $L_{\max }$ is the maximum luminance of the bright bars and $L_{\min }$ is the minimum luminance of the dark bars. The sample and plate results are shown in Table 1.

There are several other test tools to evaluate contrast sensitivity. Contrast sensitivity can be tested either by using optotype letters with decreasing contrast or sine-wave gratings with different ranges of spatial frequencies. An example of letter-contrast sensitivity test is the Pelli-Robson test, which has been used in several studies. ${ }^{23,24}$ However, one of the disadvantages of the Pelli-Robson test is that it only tests at one spatial frequency. ${ }^{23,25}$ Sine-wave gratings tests can be either generated by computer and displayed on a monitor or presented with wall chart tests. Each of these modes has its own advantages and disadvantages. The computer-generated tests are more time-consuming and expensive. However, they offer the advantage of continuous control of contrast testing levels at a wide range of spatial frequencies. ${ }^{26}$

All phacoemulsification surgeries were performed by a single surgeon with more than five years of experience (BG) in order to minimize differences in surgically induced aberration. The phacoemulsification procedures were performed using the Infiniti phacoemulsification device (Alcon, TX USA) with a $2.75 \mathrm{~mm}$ clear corneal incision. No attempts were made to correct pre-existing corneal astigmatism. The corneal wound was either hydrated or closed with nylon 10/0 and the paracentesis wound closed using the hydration method. The patients were operated as a day case under local anaesthesia.

The eyes included in the study were randomly assigned to receive either Tecnis ZA9003 ${ }^{\mathrm{TM}}$, AcrySof IQ ${ }^{\mathrm{TM}}$, or Akreos Adapt AO ${ }^{\mathrm{TM}}$ IOLs. There was no financial interest in any of the lenses used and the patients paid for the lenses unless they were government employees, in which case they were able to obtain reimbursement from the government. The cost of all the three lenses is similar in the local market. 
Table 2. IOL types and specifications

\begin{tabular}{|l|l|l|l|}
\hline & Tecnis ZA9003 $^{\text {TM }}$ & AcrySof IQ $^{\text {TM }}$ & Akreos Adapt AO $^{\text {TM }}$ \\
\hline Material & Hydrophobic acrylic & Hydrophobic acrylic & Hydrophilic acrylic \\
\hline Refractive index & 1.47 & 1.55 & 1.458 \\
\hline $\begin{array}{l}\text { Aspheric optic } \\
\text { design }\end{array}$ & $\begin{array}{l}\text { Round anterior edge } \\
\text { Square posterior } \\
\text { edge } \\
\text { Sloping side edge }\end{array}$ & $\begin{array}{l}\text { Anterior increase in } \\
\text { edge }\end{array}$ & $\begin{array}{l}\text { Biconvex aspheric } \\
\text { anterior and } \\
\text { posterior } \\
\text { Optic body is } 6 \mathrm{~mm}\end{array}$ \\
\hline $\begin{array}{l}\text { Aberration } \\
\text { correction }\end{array}$ & Cornea and lens & Cornea and lens & Lens \\
\hline Edge thickness & $\begin{array}{l}\text { Approximately } 0.50 \\
\text { mm }\end{array}$ & $0.21 \mathrm{~mm}$ & 0.31 mm \\
\hline Light filtration & UV & UV and blue light & UV \\
\hline Design & Multi-piece & Single-piece & $\begin{array}{l}\text { Single-piece, } 0^{\circ} \\
\text { angulation }\end{array}$ \\
\hline Delivery system & UNFOLDER & MONARCH II & Al-27/PS-27 inserter \\
\hline
\end{tabular}

Randomisation was achieved using a computerized randomization program by the Centre of Clinical Research in Penang, Malaysia. The primary investigator (CCYA), who evaluated the contrast sensitivity, was blinded to the type of IOL used.

Table 2 shows the specifications of the three different IOL types compared in this study. The Tecnis ZA9003 ${ }^{\mathrm{TM}}$ is a three-piece IOL with biconvex design that improves contrast sensitivity by reducing unwanted aberration. It has a square posterior edge $\left(360^{\circ}\right.$ capsular contact) which stabilizes the lens. In addition, it has a rounded anterior edge designed to scatter light and reduce internal reflections. The sloping side reduces unwanted aberration and glare. It introduces $-0.27 \mu \mathrm{m}$ of spherical aberration to the eye measured at the $6 \mathrm{~mm}$ optical zone.

The AcrySof IQTM is a single-piece, yellow-tinted acrylic hydrophobic IOL with blue light filtration that is designed for uncompromised colour perception. It reduces corneal and lens aberration by its aspheric posterior surface reduction design. Its blue light filter absorbs light wavelengths between 300 and $500 \mathrm{~nm}$, thus protecting the retinal pigment epithelium from blue light damage. Reduction of blue light on the retinal pigment epithelial cells reduces the risk of macular degeneration. It adds $-0.20 \mu \mathrm{m}$ of spherical aberration to the eye.

The Akreos Adapt $\mathrm{AO}^{\mathrm{TM}}$ is an acrylic hydrophilic IOL. It is an aberration-free lens that has aspheric anterior and posterior surfaces. They are neutral to the cornea, therefore suitable for all patients regardless of corneal shape. This aberration-free IOL leaves a small amount of positive spherical aberration from the cornea, thus increasing the depth of field compared to negative aberration lenses. Its anti-glare 
Table 3. Postoperative procedure

\begin{tabular}{|l|l|}
\hline Postoperative follow-up & Examinations and parameters recorded \\
\hline Day 1 & Slit lamp and visual acuity \\
\hline Week 1 & Slit lamp, visual acuity, and retina examination \\
\hline Week 6 & $\begin{array}{l}\text { Slit lamp and retina examination } \\
\text { LogMAR visual acuity } \\
\text { Contrast sensitivity } \\
\text { Refraction }\end{array}$ \\
\hline Week 12 & $\begin{array}{l}\text { Slit lamp and retina examination } \\
\text { LogMAR visual acuity } \\
\text { Contrast sensitivity } \\
\text { Refraction }\end{array}$ \\
\hline
\end{tabular}

technology reduces glare by having a low refractive index material and a steeper curvature of the anterior lens surface.

Routine postoperative care was a fixed combination of dexamethasone, neomycin, and polymyxin B eye drops (Maxitrol, Camberley, UK) at three hourly intervals, which was then tapered to four times a day after one week and discontinued after one month. The examinations and parameters recorded at each postoperative follow-up is summarised in Table 3. Subjects were reviewed on day 1 , week 1 , week 6 , and week 12. LogMAR visual acuity and anterior segment examination were performed at all visits. Dilated fundus examination was performed at weeks 1,6 , and 12 . This included refraction and contrast sensitivity examinations with the CSV-1000 contrast sensitivity test at weeks 6 and 12 only with BCVA by the primary investigator (CCYA).

A power and sample size calculation (PS) computer software program was used to calculate the sample size. The subjects were assigned to three groups. The level of significance, a value, was taken as 0.05 (confidence level of 95\%). The power of the study was $80 \%$. The $\sigma$ standard deviation of mean was 0.14 . The $\delta$ value, which is the detectable difference, was taken as $0.10 \mathrm{log}$ units between tests at a given spatial frequency. The ratio of control to experimental patients was $m=1$. By using the PS computer software program, the sample size for each for each of the IOLs was set at 32 .

Analysis of variance (ANOVA) was used to determine the differences in the contrast sensitivity between the Tecnis ZA9003 ${ }^{\mathrm{TM}}$, AcrySof IQ ${ }^{\mathrm{TM}}$, and Akreos Adapt $\mathrm{AO}^{\mathrm{TM}}$ groups. If the one-way ANOVA revealed a significant difference, post hoc tests with Bonferroni corrections were used to determine the differences between the specific means. A general linear model was used to analyse the pre- and postoperative contrast sensitivity for each IOL. The Statistical Package for Social Sciences (SPSS) version 17.0 was used for the statistical analysis. The accepted level of significance was set at $p<0.05$. 


\section{Results}

We were able to recruit one hundred patients in this study. However, only 96 eyes were finally analysed. Two patients were randomised but were unable to proceed with surgery because the assigned IOLs could not be obtained in time. Another patient had a medical illness and was lost to follow-up. The fourth had a posterior capsule rupture and the IOL was inserted in the sulcus. All 96 patients completed 3 months of follow-up. All groups had the same number of eyes, that is, 32 eyes. Demographical data of the patients analysed in the study are shown in Table 4.

Figure 3 shows the results of the pre- and post-operative best corrected visual acuity measured at 6 and 12 weeks for the 3 groups. There was no statistically significant difference between the groups at each postoperative period.

Table 4. Demographical data at baseline showing the mean age and gender distribution of patients implanted with the three lenses

\begin{tabular}{|l|l|l|l|l|}
\hline & $\begin{array}{l}\text { Tecnis } \\
\text { ZA9003TM }\end{array}$ & AcrySof IQTM & $\begin{array}{l}\text { Akreos Adapt } \\
\text { A0TM }\end{array}$ & P-value \\
\hline $\begin{array}{l}\text { Mean age } \\
\text { (years) } \pm \text { SD } \\
\text { (Range) }\end{array}$ & $\begin{array}{l}66.90 \pm 5.53 \\
(55-75)\end{array}$ & $\begin{array}{l}66.5 \pm 5.58 \\
(56-75)\end{array}$ & $\begin{array}{l}66.18 \pm 5.36 \\
(57-74)\end{array}$ & 0.80 \\
\hline $\begin{array}{l}\text { Ratio of } \\
\text { percentage of } \\
\text { male: female }\end{array}$ & $37: 63$ & $56: 44$ & $31: 69$ & 0.11 \\
\hline
\end{tabular}

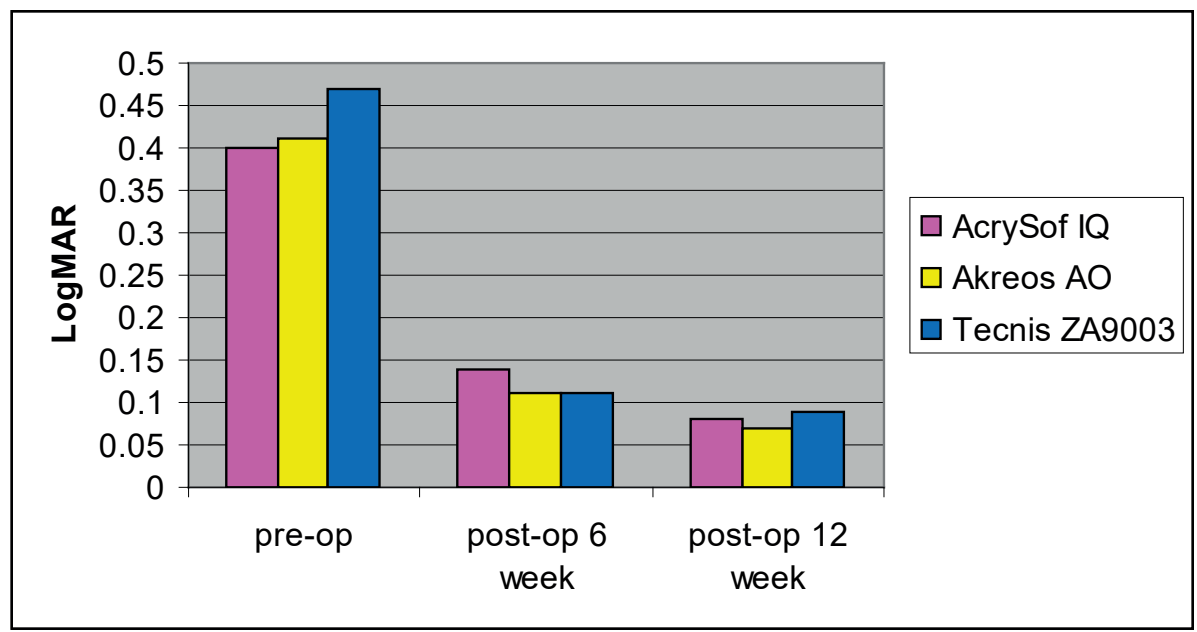

Fig. 3. Pre- and postoperative BCVA at 6 and 12 weeks. One-way repeated measure ANOVA, $p>0.05$ 
Table 5. Postoperative vision and spherical equivalent (SE)

\begin{tabular}{|l|l|l|l|l|}
\hline & $\begin{array}{l}\text { Tecnis } \\
\text { ZA9003TM }\end{array}$ & AcrySof IQTM & $\begin{array}{l}\text { Akreos Adapt } \\
\text { AOTM }\end{array}$ & P-value \\
\hline $\begin{array}{l}\text { Mean uncorrected } \\
\text { preoperative distance } \\
\text { visual acuity (UCVA) } \pm \\
\text { SD (logMAR) }\end{array}$ & $0.59 \pm 0.19$ & $0.60 \pm 0.25$ & $0.56 \pm 0.23$ & $\begin{array}{l}0.70 \\
(\mathrm{~F}=0.357)\end{array}$ \\
\hline $\begin{array}{l}\text { Mean corrected } \\
\text { preoperative distance } \\
\text { visual acuity (BCVA) } \pm \\
\text { SD }\end{array}$ & $0.47 \pm 0.12$ & $0.40 \pm 0.15$ & $0.41 \pm 0.14$ & $\begin{array}{l}0.15 \\
(\mathrm{~F}=1.896)\end{array}$ \\
\hline $\begin{array}{l}\text { Postoperative UCVA } \\
\text { Week 6 }\end{array}$ & $0.35 \pm 0.16$ & $0.35 \pm 0.15$ & $0.31 \pm 0.16$ & $\begin{array}{l}0.54 \\
(\mathrm{~F}=0.605)\end{array}$ \\
\hline $\begin{array}{l}\text { Postoperative BCVA } \\
\text { Week 6 }\end{array}$ & $0.11 \pm 0.10$ & $0.14 \pm 0.10$ & $0.11 \pm 0.10$ & $\begin{array}{l}0.48 \\
(\mathrm{~F}=0.744)\end{array}$ \\
\hline $\begin{array}{l}\text { Postoperative UCVA } \\
\text { Week 12 }\end{array}$ & $0.37 \pm 0.25$ & $0.28 \pm 0.17$ & $0.27 \pm 0.20$ & $\begin{array}{l}0.17 \\
(\mathrm{~F}=1.80)\end{array}$ \\
\hline $\begin{array}{l}\text { Postoperative BCVA } \\
\text { Week 12 }\end{array}$ & $0.09 \pm 0.09$ & $0.08 \pm 0.08$ & $0.07 \pm 0.09$ & $\begin{array}{l}0.71 \\
(\mathrm{~F}=0.342)\end{array}$ \\
\hline $\begin{array}{l}\text { Mean preoperative SE } \\
\text { (range) }\end{array}$ & $\begin{array}{l}0.37 \pm 1.45 \mathrm{D} \\
(-3.50-4.38)\end{array}$ & $\begin{array}{l}0.83 \pm 1.89 \mathrm{D} \\
(-2.75-4.25)\end{array}$ & $\begin{array}{l}0.87 \pm 1.96 \mathrm{D} \\
(-3.50-4.38)\end{array}$ & $\begin{array}{l}0.46 \\
(\mathrm{~F}=0.789)\end{array}$ \\
\hline $\begin{array}{l}\text { Mean postoperative SE } \\
\text { Week 6 (range) }\end{array}$ & $\begin{array}{l}0.13 \pm 0.98 \mathrm{D} \\
(-1.50-0.98)\end{array}$ & $\begin{array}{l}0.45 \pm 0.67 \mathrm{D} \\
(-0.38-2.25)\end{array}$ & $\begin{array}{l}0.50 \pm 1.01 \mathrm{D} \\
(-1.50-3.75)\end{array}$ & $\begin{array}{l}0.20 \\
(\mathrm{~F}=1.598)\end{array}$ \\
\hline $\begin{array}{l}\text { Mean postoperative SE } \\
\text { Week 12 (range) }\end{array}$ & $\begin{array}{l}0.22 \pm 1.02 \mathrm{D} \\
(-1.75-3.00)\end{array}$ & $\begin{array}{l}0.45 \pm 0.68 \mathrm{D} \\
(-0.75-2.25)\end{array}$ & $\begin{array}{l}0.60 \pm 0.96 \mathrm{D} \\
(-1.75-3.00)\end{array}$ & $\begin{array}{l}0.26 \\
(\mathrm{~F}=1.382)\end{array}$ \\
\hline
\end{tabular}

Table 5 shows the changes in post-operative vision and spherical equivalent. There is no statistical significance between the 3 lenses. $(F$ value $=$ variance of the group means (Mean Square Between) / mean of the within group variances (Mean Squared Error)

\section{Pre-operative contrast sensitivity}

The preoperative mean distance contrast sensitivity scores for all spatial frequencies under photopic conditions and mesopic conditions with and without glare were not statistically significant between the lenses $(p>0.05)$ (Table 6). Our results showed that mesopic contrast sensitivity with glare was the lowest compared to photopic contrast sensitivity at $3,6,12$, and 18 cpds.

\section{Postoperative contrast sensitivity}

There was no statistically significant difference between the three groups at all spatial frequencies at 6 weeks postoperative $(p>0.05)$ (Table 7$)$. There was no sta- 
Table 6. Preoperative mean contrast sensitivity scores in logarithmic value in the three IOL groups.

\begin{tabular}{|l|l|l|l|l|}
\hline \multirow{2}{*}{\begin{tabular}{l} 
Conditions \\
\cline { 2 - 5 }
\end{tabular}} & \multicolumn{3}{l}{ Mean contrast sensitivity } \\
\hline Photopic & AcrySof IQTM & $\begin{array}{l}\text { Akreos Adapt } \\
\text { AOTM }\end{array}$ & $\begin{array}{l}\text { Tecnis } \\
\text { ZA9003TM }\end{array}$ & P-value \\
\hline $\mathbf{3}$ cpd & 1.28 & 1.27 & 1.23 & 0.77 \\
\hline $\mathbf{6}$ cpd & 1.21 & 1.27 & 1.21 & 0.68 \\
\hline $\mathbf{1 2}$ cpd & 0.89 & 0.74 & 0.79 & 0.15 \\
\hline $\mathbf{1 8}$ cpd & 0.45 & 0.40 & 0.38 & 0.63 \\
\hline Mesopic, no glare & \multicolumn{3}{l|}{} \\
\hline $\mathbf{3}$ cpd & 1.19 & 1.25 & 1.20 & 0.71 \\
\hline $\mathbf{6}$ cpd & 1.18 & 1.23 & 1.20 & 0.13 \\
\hline $\mathbf{1 2}$ cpd & 0.81 & 0.78 & 0.76 & 0.76 \\
\hline $\mathbf{1 8}$ cpd & 0.41 & 0.41 & 0.39 & 0.92 \\
\hline Mesopic, with glare & & & \\
\hline $\mathbf{3}$ cpd & 1.13 & 1.16 & 1.03 & 0.22 \\
\hline $\mathbf{6}$ cpd & 1.06 & 1.16 & 1.01 & 0.10 \\
\hline $\mathbf{1 2}$ cpd & 0.77 & 0.74 & 0.72 & 0.69 \\
\hline $\mathbf{1 8}$ cpd & 0.36 & 0.36 & 0.36 & 1.00 \\
\hline
\end{tabular}

tistically significant difference between groups in the mean contrast sensitivity at 12 weeks postoperative $(p>0.05)$. (Table 7$)$

Peak sensitivity occurs near $6 \mathrm{cpd}$, which corresponds to the most sensitive part of the contrast sensitivity curve.15 The trend of the line graph showed that all 3 lenses had comparable mean contrast sensitivity value at 3 and $6 \mathrm{cpds}$ (Fig 4). Akreos AOTM, a zero aberration IOL, showed better contrast sensitivity at $12 \mathrm{cpd}$ under photopic testing, but this was not statistically significant $(p=0.48)$. The two negative aberration IOLs, AcrySof IQTM and Tecnis ZA9003TM, showed comparable mean contrast sensitivity at $12 \mathrm{cpd}$ under photopic conditions.

Even though the data analysis showed no significance in contrast sensitivity between the lenses postoperatively, the line graph showed that the zero aberration IOL $\left(A k r e o s \mathrm{AO}^{\mathrm{TM}}\right.$ ) had the lowest mean contrast sensitivity under mesopic testing without glare at $18 \mathrm{cpd}$ (Fig. 5). Tecnis ZA9003 ${ }^{\mathrm{TM}}$ had the highest mean contrast sensitivity at higher frequency testing at $18 \mathrm{cpd}$ under mesopic conditions without glare. The mean difference between the Tecnis ZA9003 ${ }^{\mathrm{TM}}$ and Akreos Adapt AO ${ }^{\mathrm{TM}}$ at $18 \mathrm{cpd}$ under mesopic testing was $10.3 \%$. However, this was not statistically 
Table 7. Postoperative mean contrast sensitivity scores in logarithmic value in the $3 \mathrm{IOL}$ groups at 6 and 12 weeks

\begin{tabular}{|c|c|c|c|c|c|c|c|c|}
\hline \multirow[t]{3}{*}{ Conditions } & \multicolumn{8}{|c|}{ Mean contrast sensitivity } \\
\hline & \multicolumn{2}{|c|}{ AcrySof IQTM } & \multicolumn{2}{|c|}{$\begin{array}{l}\text { Akreos Adapt } \\
\text { AOTM }\end{array}$} & \multicolumn{2}{|c|}{$\begin{array}{l}\text { Tecnis } \\
\text { ZA9003TM }\end{array}$} & \multicolumn{2}{|l|}{ P-value } \\
\hline & Week 6 & $\begin{array}{l}\text { Week } \\
12\end{array}$ & Week 6 & $\begin{array}{l}\text { Week } \\
12\end{array}$ & Week 6 & $\begin{array}{l}\text { Week } \\
12\end{array}$ & Week 6 & $\begin{array}{l}\text { Week } \\
12\end{array}$ \\
\hline \multicolumn{9}{|l|}{ Photopic } \\
\hline $3 \mathrm{cpd}$ & 1.70 & 1.76 & 1.75 & 1.76 & 1.74 & 1.77 & 0.47 & 0.94 \\
\hline $6 \mathrm{cpd}$ & 1.62 & 1.99 & 1.94 & 1.99 & 1.94 & 2.00 & 1.00 & 0.99 \\
\hline $12 \mathrm{cpd}$ & 1.62 & 1.66 & 1.67 & 1.72 & 1.59 & 1.66 & 0.53 & 0.48 \\
\hline $18 \mathrm{cpd}$ & 1.18 & 1.25 & 1.19 & 1.26 & 1.21 & 1.31 & 0.81 & 0.55 \\
\hline \multicolumn{9}{|c|}{ Mesopic, no glare } \\
\hline $3 \mathrm{cpd}$ & 1.68 & 1.70 & 1.66 & 1.70 & 1.72 & 1.67 & 0.35 & 0.82 \\
\hline $6 \mathrm{cpd}$ & 1.88 & 1.91 & 1.86 & 1.90 & 1.88 & 1.95 & 0.94 & 0.65 \\
\hline 12 cpd & 1.59 & 1.63 & 1.58 & 1.64 & 1.57 & 1.67 & 0.95 & 0.77 \\
\hline $18 \mathrm{cpd}$ & 1.15 & 1.26 & 1.19 & 1.21 & 1.20 & 1.35 & 0.78 & 0.09 \\
\hline \multicolumn{9}{|c|}{ Mesopic, with glare } \\
\hline $3 \mathrm{cpd}$ & 1.66 & 1.69 & 1.63 & 1.67 & 1.65 & 1.68 & 0.75 & 0.88 \\
\hline $6 \mathrm{cpd}$ & 1.91 & 1.80 & 1.85 & 1.85 & 1.84 & 1.90 & 0.49 & 1.39 \\
\hline $12 \mathrm{cpd}$ & 1.55 & 1.62 & 1.60 & 1.58 & 1.50 & 1.62 & 0.28 & 0.80 \\
\hline 12 cpd & 1.11 & 1.24 & 1.14 & 1.19 & 1.13 & 1.26 & 0.85 & 0.58 \\
\hline
\end{tabular}

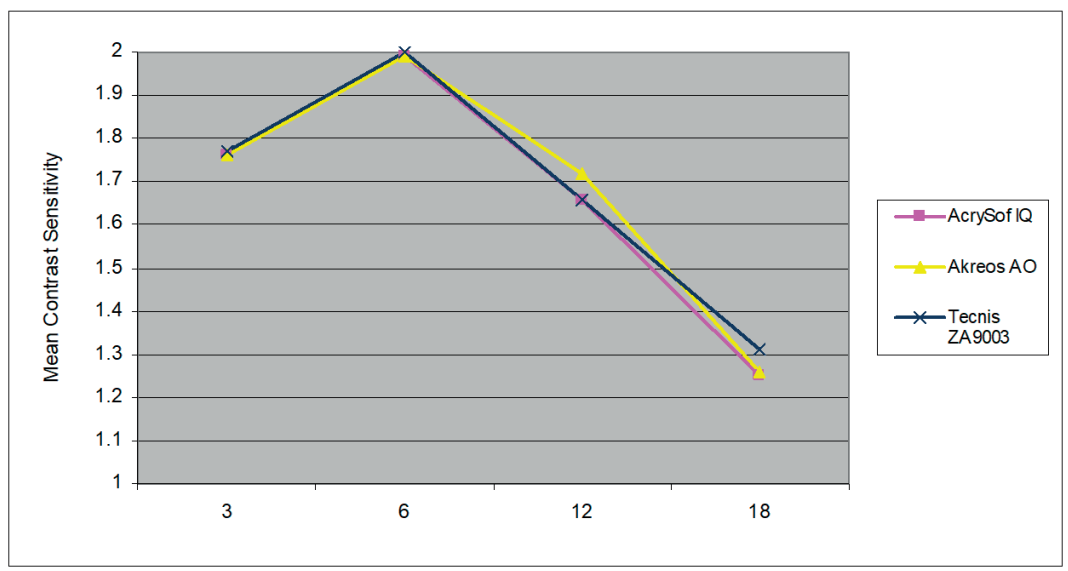

Fig. 4. Comparison of mean contrast sensitivity values between the 3 IOL groups under photopic conditions at week 12. One-way ANOVA test, $p>0.05$. 
significant $(p=0.09)$.

All three lenses showed comparable mean contrast sensitivity at all spatial frequencies under mesopic testing with glare. There was no significant difference between the groups ( $p>0.05$ ) (Fig. 6).

General linear model with post hoc Bonferroni test:

1. AcrySof IQTM, $F=26.75, p=0.0$;

2. Akreos Adapt AOTM, $F=17.99, p=0.0$; and

3. Tecnis ZA9003TM, $F=17.00, p=0.0$

There was statistically significant improvement in the uncorrected postoperative mean logMAR at weeks 6 and 12 compared with preoperatively for all IOL groups. There were no significant changes found between the week 6 and week 12 mean

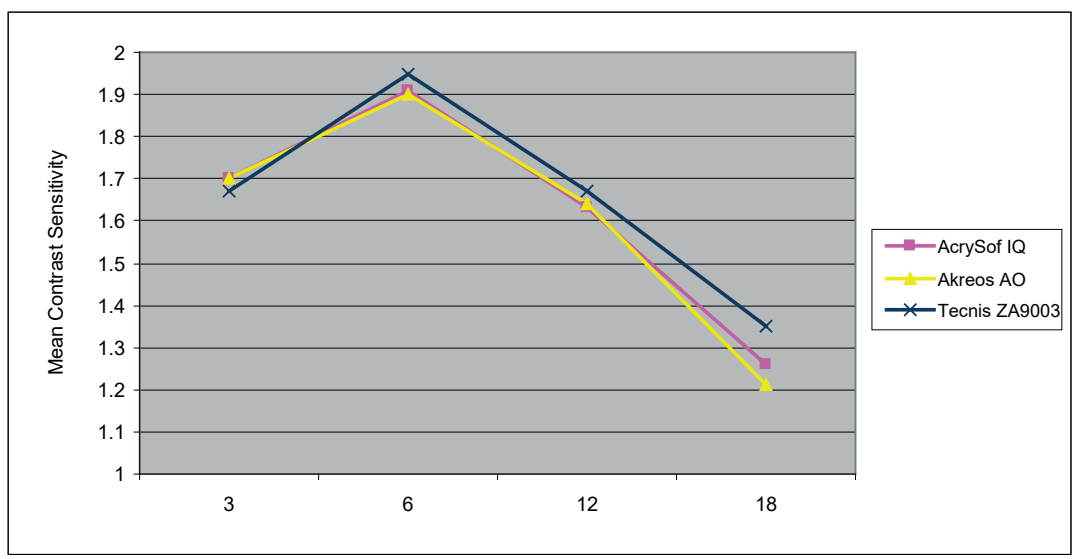

Fig. 5. Comparison of mean contrast sensitivity values between the $3 \mathrm{IOL}$ groups under mesopic conditions without glare at week 12. One-way ANOVA test, $p>0.05$.

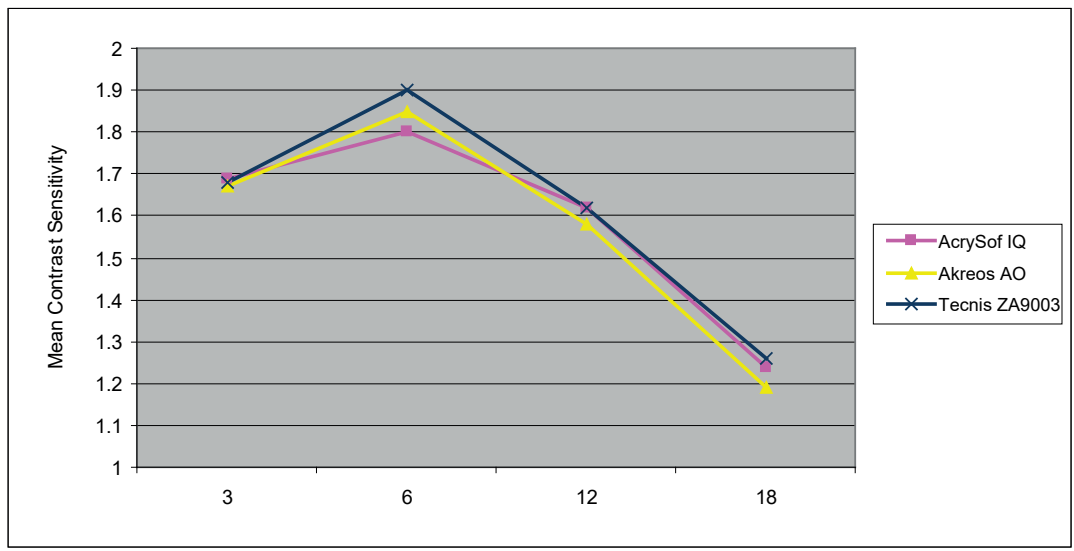

Fig. 6. Comparison of mean contrast sensitivity values between the three IOL groups under mesopic conditions with glare at week 12. One-way ANOVA test, $p>0.05$. 
$\log$ MAR $(p 1=0.24, p 2=0.28, p 3=1.0)($ Fig. 7$)$.

General linear model with post hoc Bonferroni test:

1. AcrySof IQTM, $F=84.96, p=0.0$;

2. Akreos Adapt AOTM, $F=86.99, p=0.0$;

3. Tecnis ZA9003TM, $F=131.57, p=0.0$

Our data analysis showed statistically significant improvement between pre- and postoperative BCVA at weeks 6 and 12 for all IOL groups (Fig. 8). Both the AcrySof

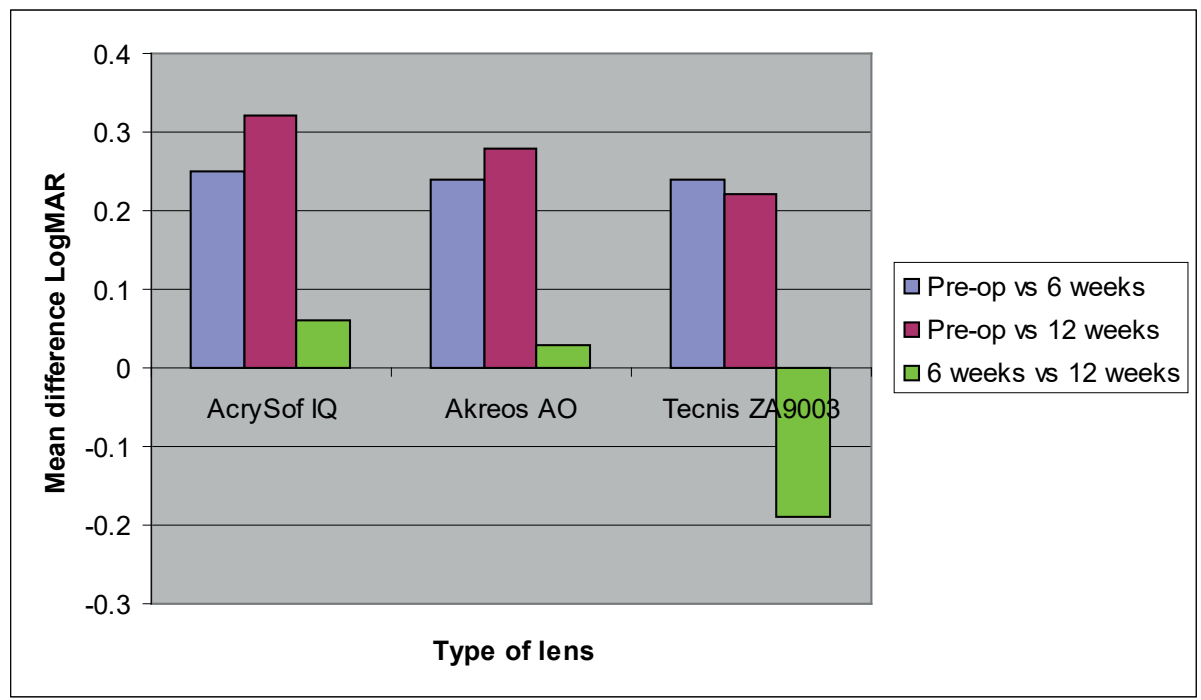

Fig. 7. Comparison of mean difference between uncorrected pre- and postoperative logMAR vision for each of the three IOL groups.

IQTM and Akreos Adapt AOTM groups also showed significant improvement in visual acuity between 6 and 12 weeks $(p 1=0.00, p 2=0.04)$. There were no statistically significant changes found in the Tecnis ZA9003TM group at 6 and 12 weeks (p3=0.57).

In comparing pre- and postoperative contrast sensitivity, our analysis showed that all three IOLs showed statistically significant improvement at all spatial frequencies under photopic, mesopic without glare, and mesopic with glare conditions following surgery at week 12 compared to baseline preoperative levels $(\mathrm{p}<0.05)$ (Fig. 9 A-C).

Figure 10 illustrates that Tecnis $Z A 9003^{\mathrm{TM}}$ showed a statistically significant improvement of $12 \%$ in the contrast sensitivity at $18 \mathrm{cpd}$ under mesopic testing without glare between week 6 and 12 week postoperatively. Akreos Adapt AO TM and AcrySof IQ ${ }^{\mathrm{TM}}$ showed slight improvement, but not statistically significant, from week 6 to week 12 . 


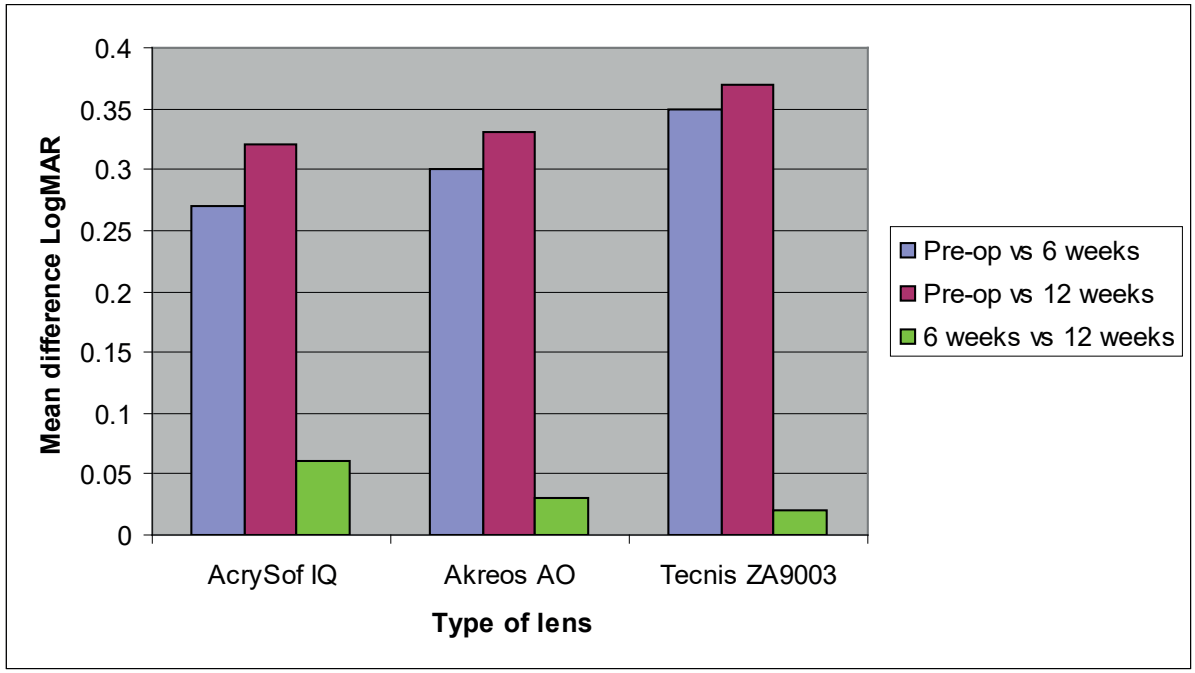

Fig. 8. Comparison of mean difference between corrected pre- and postoperative logMAR vision for each of the three IOL groups.

Akreos Adapt AOTM, a zero aberration IOL, showed slightly higher contrast sensitivity at photopic testing in comparison to the negative aberration IOLs (AcrySof IQTM and Tecnis ZA9003TM) (Fig. 11). However, this was not significant as the difference was only $3.5 \%(p=0.48)$.

In studying the performance of Akreos Adapt AOTM, we found that the contrast sensitivity drop from photopic to mesopic testing (with and without glare) was statistically significant at $12 \mathrm{cpd}$ at 12 weeks (Fig. 11). There was a $4.6 \%$ drop in contrast from photopic to mesopic without glare and 3.6\% drop at mesopic with glare. The total drop of contrast sensitivity from photopic to mesopic with glare was $8 \%$. The negative aberration IOLs, Tecnis ZA9003TM and AcrySof IQTM, did not show any statistically significant drop at mesopic testing with or without glare.

Tecnis ZA9003TM showed a slight improvement of $5.8 \%$ at 12 weeks in contrast sensitivity from photopic to mesopic testing without glare. However, this was not statistically significant $(p=0.79)$.

\section{Discussion}

Cataract surgery has evolved over the years from only removing the cataract and implanting an IOL in order to improve visual acuity to improving functional vision in terms of better contrast sensitivity and correction of astigmatism with toric IOLs with various lens designs and materials. Contrast sensitivity of patients with spherical IOL implants was found to be the same as those with crystalline lens. ${ }^{12}$ 

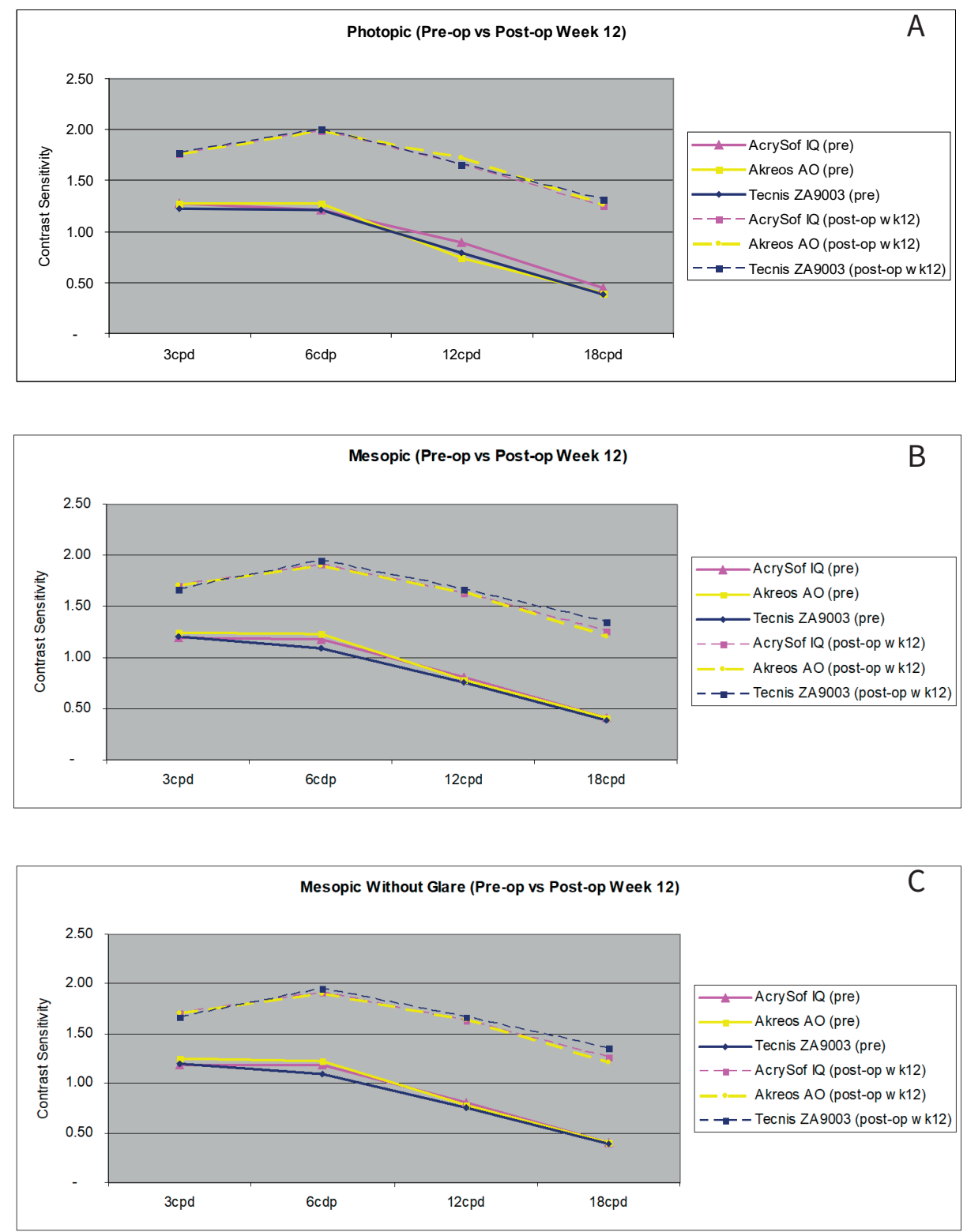

Fig. 9. $(A-C)$ Comparison between pre- and postoperative combined lens mean contrast sensitivity under photopic, mesopic without glare, and mesopic with glare at different spatial frequencies. 


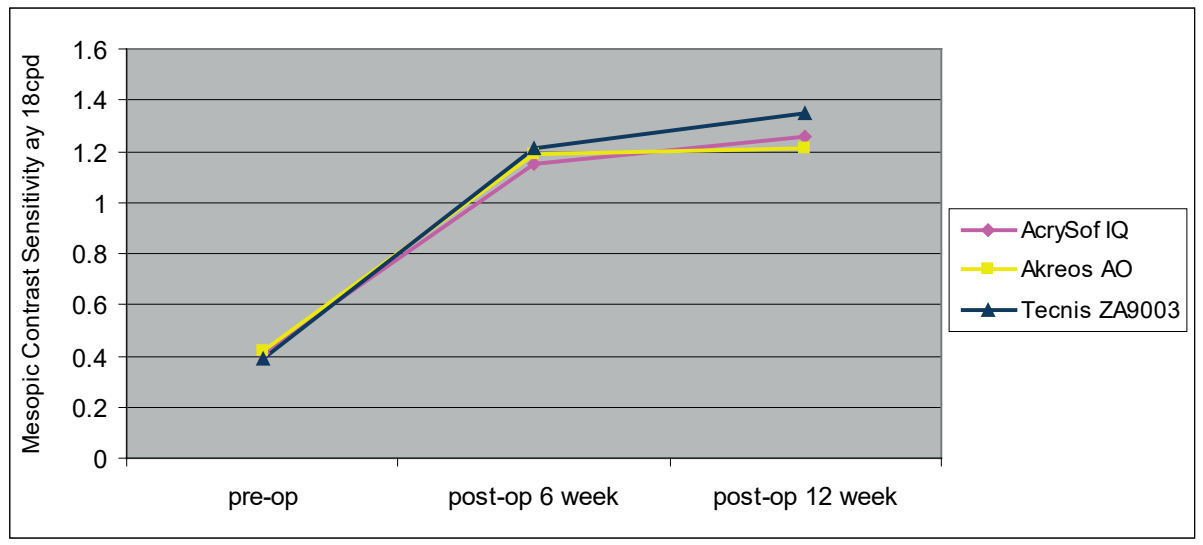

Fig. 10. Comparison between contrast sensitivity at pre- and postoperative weeks 6 and 12 under mesopic conditions without glare at $18 \mathrm{cpd}$. One-way ANOVA, (test within subject effect). For Tecnis ZA9003TM, $F=189.03, p=0.001$ for week 6 vs week 12 .

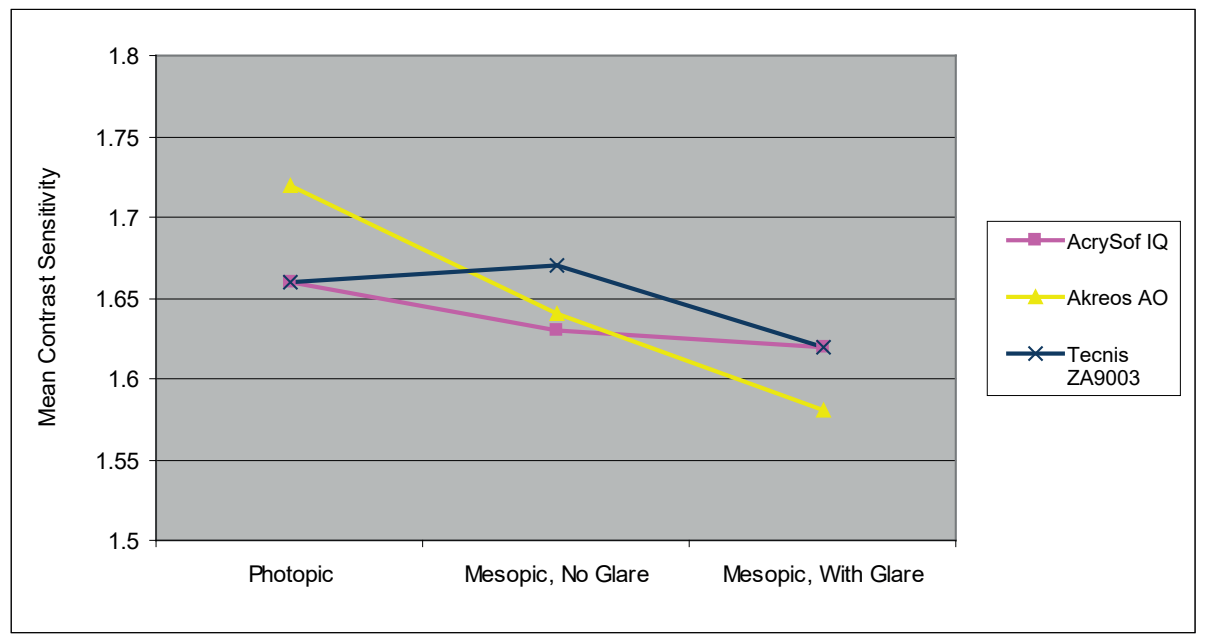

Fig. 11. Comparison between postoperative contrast sensitivity under photopic, mesopic without glare, and mesopic with glare at $12 \mathrm{cpd}$ for each IOL group at week 12. Paired T-test (2-tailed). For Akreos Adapt AOTM, $t=-2.55$ (mesopic without glare vs photopic), $p=0.16$, $\mathrm{t}=-3.94$ (mesopic with glare vs photopic), $\mathrm{p}=0.00$. 
Contrast sensitivity as measured with the CSV 1000 has been used as a research tool in various studies. ${ }^{4,14,16,18,27,28}$ In addition, the halogen light source from the CVS 1000 HGT allows the measurement of glare at mesopic testing, which provides additional assessment for the optical performance of these lenses. Contrast sensitivity has been reported to decrease with age, affecting mesopic contrast sensitivity. ${ }^{29}$

Our results show that, preoperatively, there were no statistically significant differences between the three groups in terms of visual acuity, spherical equivalent, cylindrical powers, and age. Postoperatively, all three IOLs showed significant improvement in UCVA and BCVA. All three IOLs performed equally well in distance visual acuity postoperatively. This result concurs with the findings of other investigators. ${ }^{13,17,30}$ Nabh et al., who also studied the Tecnis ZA90003 ${ }^{\mathrm{TM}}$, AcrySof IQ ${ }^{\mathrm{TM}}$, and Akreos Adapt $\mathrm{AO}^{\mathrm{TM}}$ similarly found that postoperative gains in visual acuity were comparable. ${ }^{23}$

Preoperatively, all patients in the three IOL groups had the lowest level of contrast sensitivity in all lighting conditions, especially in mesopic testing with glare. The poorer contrast sensitivity reflects the effect of cataract on the loss of contrast sensitivity. Many patients with cataract have reported worsening of visual performance when associated with glare at night while driving. ${ }^{8}$ Our results showed that, at mesopic testing with glare at $3,6,12$, and $18 \mathrm{cpds}$, the contrast sensitivity result was the lowest compared to photopic testing.

Our study showed that the postoperative mean log contrast sensitivity was not statistically significant between these three aspheric IOLs. This concurs with other studies ${ }^{17,23,30}$ that showed equal performance in contrast sensitivity between aspheric lenses. Nabh et al. conducted a similar study comparing contrast sensitivity between Tecnis ZA9003 ${ }^{\mathrm{TM}}$, AcrySof IQ ${ }^{\mathrm{TM}}$, and Akreos Adapt AO ${ }^{\mathrm{TM}}$. However, they used the Pelli-Robson contrast sensitivity chart, which only measures contrast sensitivity at one spatial frequency and without mesopic testing with and without glare. They similarly found no statistically significance between the mean contrast sensitivity values. ${ }^{23}$ Johannsson et al. reported that Akreos Adapt $\mathrm{AO}^{\mathrm{TM}}$ and Tecnis ZA9000 ${ }^{\mathrm{TM}}$ gave similar photopic and mesopic contrast sensitivities. ${ }^{30}$ They used the Functional Acuity Contrast Test charts under photopic and mesopic testing without glare. However, they did not test for contrast sensitivity with glare. Despite the equal performance in contrast sensitivity, they found that Tecnis $Z 9000^{\mathrm{TM}}$ gave significantly less spherical aberration compared to Akreos Adapt $\mathrm{AO}^{\mathrm{TM}}$ using an aberrometer. ${ }^{30}$ This could explain better mesopic contrast sensitivity results with Tecnis in our study. However, we could not confirm this finding without a wavefront analysis. Our study reinforces the findings in previous studies using the CSV 1000 tool for measuring contrast sensitivity.

Even though our study did not show statistically significant differences between the IOLs, our data analysis showed that negative aberration IOLs (Tecnis ZA9003 ${ }^{\mathrm{TM}}$ and AcrySof $\left(\mathrm{Q}^{\mathrm{TM}}\right.$ ) had better contrast sensitivity values at mesopic testing at higher 
frequencies compared to the zero aberration IOL (Akreos Adapt $\mathrm{AO}^{\mathrm{TM}}$ ). In our study, Tecnis ZA9003 ${ }^{\mathrm{TM}}$ showed significant improvement (12\%) at mesopic testing without glare at $18 \mathrm{cpd}$ between weeks 6 and 12 postoperative. In studying mesopic contrast sensitivity at $12 \mathrm{cpd}$, we found that negative aberration lenses, Tecnis ZA9003 ${ }^{\mathrm{TM}}$ and AcrySof IQ ${ }^{\mathrm{TM}}$, did not show any statistically significant drop in contrast sensitivity. On the contrary, Akreos Adapt $\mathrm{AO}^{\mathrm{TM}}$ showed $8 \%$ contrast sensitivity drop from photopic to mesopic testing with glare, which was statistically significant. This useful information may influence IOL selection for patients who frequently move between light and dark environments, including retinal surgeons.

A study conducted by Denoyer et al. found similar results to our study. ${ }^{13}$ They compared a negative-aberration IOL (Tecnis Z9000, Advanced Medical Optics, CA, USA) and a zero aberration IOL (SofPort AO, Bausch and Lomb, Quebec, Canada). Their results showed that mesopic contrast sensitivity was statistically better in the negative-aberration IOL group at intermediate and high frequencies. ${ }^{12}$ In addition, they also found that the zero aberration group (SofPort AO) performed better at photopic contrast sensitivity. This result is similar to our study at week 12 , where Akreos Adapt $\mathrm{AO}^{\mathrm{TM}}$ had the highest contrast sensitivity at $12 \mathrm{cpd}$ under photopic testing. However, this finding was not statistically significant in our study. This could be due to our smaller sample size compared to Denoyer et al., which had 40 patients in each group.

AcrySof $\mathrm{IQ}^{\mathrm{TM}}$ is a yellow-tinted IOL designed with a modified posterior surface for improving contrast sensitivity. It has been proposed that yellow filters can improve contrast sensitivity at medium spatial frequencies under mesopic testing, ${ }^{6,14,18}$ reducing glare and increasing apparent brightness in daylight conditions. ${ }^{29}$ However, other studies showed no difference in the contrast sensitivity between the yellow-tinted Alcon SN60AT (Alcon Laboratories, TX, USA) and clear Alcon SA60AT4. ${ }^{27}$ Our study showed that AcrySofIQ ${ }^{\mathrm{TM}}$ with the yellow tint performed equally well in contrast sensitivity with clear aspheric IOLs. This result is similarly found in a study conducted by Nabh et al. comparing the AcrySofIQ ${ }^{\mathrm{TM}}$ and Tecnis $\mathrm{ZA9003}^{\mathrm{TM}} .{ }^{23}$

There have been concerns among some researchers that yellow-tinted IOLs may affect visual function negatively. It has been reported that patients with yellow-tinted lens, in this case the Alcon SN60AT have lower luminance and require more blue light to perceive the same amount of luminance. ${ }^{31}$ Schwiegerling et al. showed that there is a reduction in scotopic vision of $14 \%$ in yellow- tinted IOLs compared to clear IOLs. ${ }^{32}$ AcrySof IQ uses the same platform as SN60AT. We can assume that AcrySof $\mathrm{IQ}^{\mathrm{TM}}$ would also have lower luminance contrast. In our study, however, AcrySof IQ ${ }^{\mathrm{TM}}$ showed no statistically significant decrease in mesopic contrast sensitivity. In fact, our results demonstrate that the yellow-tinted Acrysof $\mathrm{IQ}^{\mathrm{TM}}$ showed comparable performance with a clear negative aberration aspheric IOL (Tecnis ZA9003 ${ }^{\mathrm{TM}}$ ) at mesopic testing with and without glare. This is interesting and useful information for patients who have a family history of age-related macular degeneration who would like to have a blue light-blocking IOL implantation. Patients can be reassured 
of the comparable luminance contrast to clear lenses.

The effect of pupil bias, whereby larger pupils result in greater spherical aberration, was overcome by using of a $5 \mathrm{~mm}$ artificial pupil in this study. We limited the study of contrast sensitivity by using a standard $5 \mathrm{~mm}$ pupil size in dilated eyes. Our results may have shown more significant difference had we used a larger pupil size, for example, a $6 \mathrm{~mm}$ pupil. Larger pupils have been shown to have greater higher-order aberration, ${ }^{17,30}$ the true aspherical value of the IOLs being more evident during mesopic testing with a larger pupil.

There were several limitations to this study. One of the limitations is that the extreme range of cylindrical power and spherical powers were not excluded. Although all study subjects were examined with the best-corrected spectacles in place to ensure optimal performance, we were unable to assess the effect of corrective lenses on the contrast sensitivity evaluation. Postoperative cystoid macula oedema can also affect contrast sensitivity. Even though we examined the macula postoperatively for macula oedema, we are unable to exclude any occult cystoid macular oedema, as we did not perform any fundus fluorescence angiography or ocular coherence tomography.

There was no objective assessment of postoperative posterior capsular opacification (PCO) using any grading method. However, the follow-up period for this study was relatively short, only up to three months. The literature has reported that the incidence of PCO and rate of Nd-Yag capsulotomy is low, and the mean time of surgery to documentation PCO was $10.3 \pm 5.3$ months for Acrysof IQ ${ }^{\mathrm{TM}}$. It would be ideal to follow up for more than one year to assess the long-term visual outcomes of these IOLs.

Another limitation includes comparing Tecnis ZA9003 ${ }^{\mathrm{TM}}$ which is a three-piece $I O L$, with AcrySof $\mathrm{IQ}^{\mathrm{TM}}$ and Akreos Adapt $\mathrm{AO}^{\mathrm{TM}}$, which are single-piece IOLs. The three-piece design is more stable in the bag. In our study, we did not assess for any degree of decentration and tilt. It has been reported that negative aberration IOLs are more sensitive to decentration and tilt and may perform worse than conventional IOLs. ${ }^{11}$ Recently, a new single-piece Tecnis IOL has been released in the market. Future studies involving the new Tecnis would be ideal to standardize the IOLs to single-piece design in order to avoid bias.

In this study, we only assessed the contrast sensitivity as a measure of functional vision. It would be ideal to correlate the contrast sensitivity outcome with the wavefront analysis of the postoperative spherical aberration in future studies. Baseline measurement of the patient's corneal spherical aberration and customising the selection of aspheric IOL perhaps will allow us to better assess the performance of these lenses.

\section{Conclusions}


This study showed that AcrySof IQ ${ }^{\mathrm{TM}}$, Akreos Adapt AO ${ }^{\mathrm{TM}}$, and Tecnis ZA9003 ${ }^{\mathrm{TM}}$ have comparable visual performance in terms of BCVA and contrast sensitivity. The visual outcomes were excellent, with significant better BCVA and contrast sensitivity after surgery than at baseline. AcrySof $\mathrm{IQ}^{\mathrm{TM}}$, Adapt Akreos $\mathrm{AO}^{\mathrm{TM}}$, and Tecnis ZA9003 ${ }^{\mathrm{TM}}$ performed equally well in contrast sensitivity at all spatial frequencies under photopic, mesopic without glare, and mesopic with glare testing. The negative aberration Tecnis $\mathrm{ZA} 90 \mathrm{3}^{\mathrm{TM}}$ showed marked improvement in mesopic contrast sensitivity at $18 \mathrm{cpd}$ at 12 weeks. The zero aberration IOL, Akreos Adapt AO ${ }^{\mathrm{TM}}$, showed better photopic contrast sensitivity compared to mesopic contrast sensitivity.

\section{Acknowledgements}

This study is registered with the Secretariat National Institutes of Health (NIH), Ministry of Health Malaysia under project code MRG-2007-04.

We would like to acknowledge Dr. Intan Hafizah binti Hamzah and En Mohd Hairul Nizam bin Harun, our research officers, for their efforts in formatting and preparing this manuscript for publication.

\section{References}

1. Seah SKL, Wong TY, Foster PJ, Ng TP, Johnson GJ. Prevalence of lens opacity in Chinese residents of Singapore: the Tanjong Pagar survey. Ophthalmology. 2002;109(11):2058-2064.

2. Zainal M, Ismail SM, Ropilah AR, et al. Prevalence of blindness and low vision in Malaysian population: results from the National Eye Survey 1996. Br J Ophthalmol. 2002;86(9):951-956.

3. Goh PP. Cataract Surgery Registry. In: Goh PP, Salowi MA, Azlina M, Tassha HA, Nadiah S, editors. Tenth Report of the National Eye Database 2016.. Selangor: National Eye Database Coordinating Centre; c2018. p. 47.

4. Sandoval HP, Fernández de Castro LE, Vroman DT, Solomon KD. Comparison of visual outcomes, photopic contrast sensitivity, wavefront analysis, and patient satisfaction following cataract extraction and IOL implantation: aspheric vs spherical acrylic lenses. Eye. 2008;22(12):1469-1475.

5. Kershner RM. Retinal image contrast and functional visual performance with aspheric, silicone, and acrylic intraocular lenses: prospective evaluation. J Cataract Refract Surg. 2003;29(9):1684-1694.

6. Nanavaty MA, Spalton DJ, Boyce J, Saha S, Marshall J. Wavefront aberrations, depth of focus, and contrast sensitivity with aspheric and spherical intraocular lenses: Fellow-eye study. J Cataract Refract Surg. 2009;35(4):663-71.

7. The importance of measuring contrast sensitivity in cases of visual disturbance. Br J Ophthalmol. [Internet]. [cited 2019 May 23]. Available from: https://bjo.bmj.com/content/62/4/198.short

8. Pomerance GN, Evans DW. Test-retest reliability of the CSV-1000 contrast test and its relationship to glaucoma therapy. Invest Ophthalmol Vis Sci. 1994;35(9):3357-3361. 
9. Owsley C, McGwin G, Scilley K, Kallies K. Development of a questionnaire to assess vision problems under low luminance in age-related maculopathy. Invest Ophthalmol Vis Sci. 2006;47(2):528-535.

10. Scilley K, Jackson GR, Cideciyan AV, Maguire MG, Jacobson SG, Owsley C. Early age-related maculopathy and self-reported visual difficulty in daily life. Ophthalmology. 2002;109(7):1235-1242.

11. Eppig T, Scholz K, Löffler A, Meßner A, Langenbucher A. Effect of decentration and tilt on the image quality of aspheric intraocular lens designs in a model eye. J Cataract Refract Surg. 2009;35(6):10911100.

12. Rękas M, Krix-Jachym K, Żelichowska B, Ferrer-Blasco T, Montés-Micó R. Optical quality in eyes with aspheric intraocular lenses and in younger and older adult phakic eyes: Comparative study. J Cataract Refract Surg. 2009;35(2):297-302.

13. Denoyer A, Denoyer L, Halfon J, Majzoub S, Pisella P-J. Comparative study of aspheric intraocular lenses with negative spherical aberration or no aberration. J Cataract Refract Surg. 2009;35(3):496503.

14. Pandita D, Raj SM, Vasavada VA, Vasavada VA, Kazi NS, Vasavada AR. Contrast sensitivity and glare disability after implantation of AcrySof IQ Natural aspherical intraocular lens: Prospective randomized masked clinical trial. J Cataract Refract Surg. 2007;33(4):603-610.

15. Wang L, Koch DD. Ocular higher-order aberrations in individuals screened for refractive surgery. J Cataract Refract Surg. 2003;29(10):1896-1903.

16. Tzelikis PF, Akaishi L, Trindade FC, Boteon JE. Spherical Aberration and Contrast Sensitivity in Eyes Implanted with Aspheric and Spherical Intraocular Lenses: A Comparative Study. Am J Ophthalmol. 2008;145(5):827-833.e1.

17. Yamaguchi T, Dogru M, Yamaguchi K, et al. Effect of spherical aberration on visual function under photopic and mesopic conditions after cataract surgery. J Cataract Refract Surg. 2009;35(1):57-63.

18. Tzelikis PF, Akaishi L, Trindade FC, Boteon JE. Ocular aberrations and contrast sensitivity after cataract surgery with AcrySof IQ intraocular lens implantation: Clinical comparative study. J Cataract Refract Surg. 2007;33(11):1918-1924.

19. Bellucci R, Scialdone A, Buratto L, Morselli S, Chierego C, Criscuoli A, et al. Visual acuity and contrast sensitivity comparison between Tecnis and AcrySof SA60AT intraocular lenses: A multicenter randomized study. J Cataract Refract Surg. 2005;31(4):712-717.

20. Kurz S, Krummenauer F, Thieme H, Dick HB. Contrast sensitivity after implantation of a spherical versus an aspherical intraocular lens in biaxial microincision cataract surgery. J Cataract Refract Surg. 2007;33(3):393-400.

21. Kasper T, Bühren J, Kohnen T. Visual performance of aspherical and spherical intraocular lenses: Intraindividual comparison of visual acuity, contrast sensitivity, and higher-order aberrations. J Cataract Refract Surg. 2006;32(12):2022-2029.

22. Steinert RF. In: Steinert RF. Cataract Surgery: Technique, Complications, and Management. Philadelphia: W.B Saunders.c1995; p10-21.

23. Nabh R, Ram J, Pandav SS, Gupta A. Visual performance and contrast sensitivity after phacoemulsification with implantation of aspheric foldable intraocular lenses. J Cataract Refract Surg. 2009;35(2):347-353. 
24. Rocha KM, Soriano ES, Chalita MR, et al. Wavefront analysis and contrast sensitivity of aspheric and spherical intraocular lenses: a randomized prospective study. Am J Ophthalmol. 2006;142(5):750756.e3.

25. Pesudovs K, Hazel CA, Doran RML, Elliott DB. The usefulness of Vistech and FACT contrast sensitivity charts for cataract and refractive surgery outcomes research. Br J Ophthalmol. 2004;88(1):11-16.

26. van Gaalen KW, Jansonius NM, Koopmans SA, Terwee T, Kooijman AC. Relationship between contrast sensitivity and spherical aberration: comparison of 7 contrast sensitivity tests with natural and artificial pupils in healthy eyes. J Cataract Refract Surg. 2009;35(1):47-56.

27. Rodríguez-Galietero A, Montés-Micó R, Muñoz G, Albarrán-Diego C. Comparison of contrast sensitivity and color discrimination after clear and yellow intraocular lens implantation. J Cataract Refract Surg. 2005;31(9):1736-1740.

28. Muñoz G, Albarrán-Diego C, Montés-Micó R, Rodríguez-Galietero A, Alió JL. Spherical aberration and contrast sensitivity after cataract surgery with the Tecnis $Z 9000$ intraocular lens. J Cataract Refract Surg. 2006;32(8):1320-1327.

29. Guirao A, González C, Redondo M, Geraghty E, Norrby S, Artal P. Average optical performance of the human eye as a function of age in a normal population. Invest Ophthalmol Vis Sci. 1999;40(1):203213.

30. Johansson B, Sundelin S, Wikberg-Matsson A, Unsbo P, Behndig A. Visual and optical performance of the Akreos Adapt Advanced Optics and Tecnis Z9000 intraocular lenses: Swedish multicenter study. J Cataract Refract Surg. 2007;33(9):1565-1572.

31. Pierre A, Wittich W, Faubert J, Overbury O. Luminance contrast with clear and yellow-tinted intraocular lenses. J Cataract Refract Surg. 2007;33(7):1248-1252.

32. Schwiegerling J. Blue-light-absorbing lenses and their effect on scotopic vision. J Cataract Refract Surg. 2006;32(1):141-4. 